\title{
Natuurlijk fysiotherapie
}

\author{
Citation for published version (APA):
}

de Bie, R. A. (2003). Natuurlijk fysiotherapie. Maastricht University. https://doi.org/10.26481/spe.20031211rb

Document status and date:

Published: 11/12/2003

DOI:

10.26481/spe.20031211rb

Document Version:

Publisher's PDF, also known as Version of record

\section{Please check the document version of this publication:}

- A submitted manuscript is the version of the article upon submission and before peer-review. There can be important differences between the submitted version and the official published version of record.

People interested in the research are advised to contact the author for the final version of the publication, or visit the DOI to the publisher's website.

- The final author version and the galley proof are versions of the publication after peer review.

- The final published version features the final layout of the paper including the volume, issue and page numbers.

Link to publication

\footnotetext{
General rights rights.

- You may freely distribute the URL identifying the publication in the public portal. please follow below link for the End User Agreement:

www.umlib.nl/taverne-license

Take down policy

If you believe that this document breaches copyright please contact us at:

repository@maastrichtuniversity.nl

providing details and we will investigate your claim.
}

Copyright and moral rights for the publications made accessible in the public portal are retained by the authors and/or other copyright owners and it is a condition of accessing publications that users recognise and abide by the legal requirements associated with these

- Users may download and print one copy of any publication from the public portal for the purpose of private study or research.

- You may not further distribute the material or use it for any profit-making activity or commercial gain

If the publication is distributed under the terms of Article $25 \mathrm{fa}$ of the Dutch Copyright Act, indicated by the "Taverne" license above, 
Natuurlijk Fysiotherapie 


\section{Colofon}

Basisontwerp en realisatie Unigraphic, Universitert Masstricht

$198 \mathrm{~N} 90 \cdot 5687+191-6$

NUR 894

Alle rechtern voorbehowden. Niets wit deze uitgave mag worden verveetwoudigd, opgesiggen in een geautomatiseerd gegewensbestand of openbaar gemaakt, zonder woorafgaande schrifteHake tosteming van de auteur of witgever. 


\section{Natuurlijk Fysiotherapie}

\section{Openbare rede}

uitgesproken bij de aanvaarding van het ambt van profilerings hoogleraar Research in Physiotherapy aan de Universiteit Maastricht op donderdag 11 december 2003

door

dr. Rob A. de Bie

u 



\section{Inhoudsopgave}

Prof. Dr. Rob A. de Ble, Universiteit Maastricht

Natuurlijk Fysiotherapie

Inleiding

De verwetenschappelijking van de fysiotherapie 12

Fysiotherapie onderzoek in Mastricht 14

Richtllijnen 17

Vrije toegankelijkheid 21

Wetenschap en fysiotherapie: een haat-liefde verhouding 23

Toekomstig onderzoek $\quad 26$

De toekomst. 28

Dankwoord 30

Referenties 32 


\section{Inleiding}

Mijnheer de Rector Magnificus.

beste collega's, vrienden, familie en genodigden.

Stel, u loopt op het sportveld een sportblessure op - door wie wordt u in negen van de tien gevallen behandeld - natuurlijk $k_{\text {d }}$ de fysiotherapeut.

Stel, u bent op zondag nog even bezig in de tuin en gaat door uw rug. wie staat er na verloop van tijd voor u klaar - natuurlijk, de fysiotherapeut.

Stel, u woont in een verzorgingstehuis. Van wie krijgt u reactiveringstraining? Natuurlijk de fysiotherapeut.

Stel, u krijgt last van uw gewrichten door arthrose - wie houdt u aar de gang of aan het werk met adviezen en bewegingstips - natuurlijk, de fysiotherapeut.

$U$ komt moeilijk op gang na een zware bevalling en de diagnose luidt bekkenpijn - de fysiotherapeut zorgt dat u weer uw dagelijkse activitelten kunt hervatten.

Ik zou deze rede met gemak kunnen vullen met honderden voorbeelden waarin de fysiotherapeut een cruciale schakel vormt bij het begeleiden van de bewegende mens, zowel in curatief als preventief opzicht.

In Nederland zijn momenteel meer dan 19.000 fysiotherapeuten werkzaam, waarvan 13.500 extramuraal en 5.500 intramuraal. Ruim $90 \%$ van de patiënten die zij behandelen is werwezen door de huisarts". De huisarts werwees in 2001 gemiddeld 78 keer (per 1000 ingeschreven patienten) naar een fysiotherapeut?.

Het aantal behandelingen fysiotheraple is het afgelopen decennium gegroeid, evenals het aantal personen dat de fysiotherapeut bezocht. In 1993 had nog $13.7 \%$ wan de bevolking contact met de fysiotherapeut, in 2002 bezochten al ruim $17 \%$ van de Nederlanders de fysiotherapeut:

Bij chronisch zieken ligt dit percentage hoger, namelijk $25 \%$. In meer dan $80 \%$ van alle verwijzingen betrof het patienten met klachten alan het bewegingsapparaat en ruim $15 \%$ werd doorverwezen wegens klach- 
ten aan het zenuwstelsel en/of de zintuigen'. De overige verwijzingen betroffen grotendeels aandoeningen aan het ademhalingsapparaat.

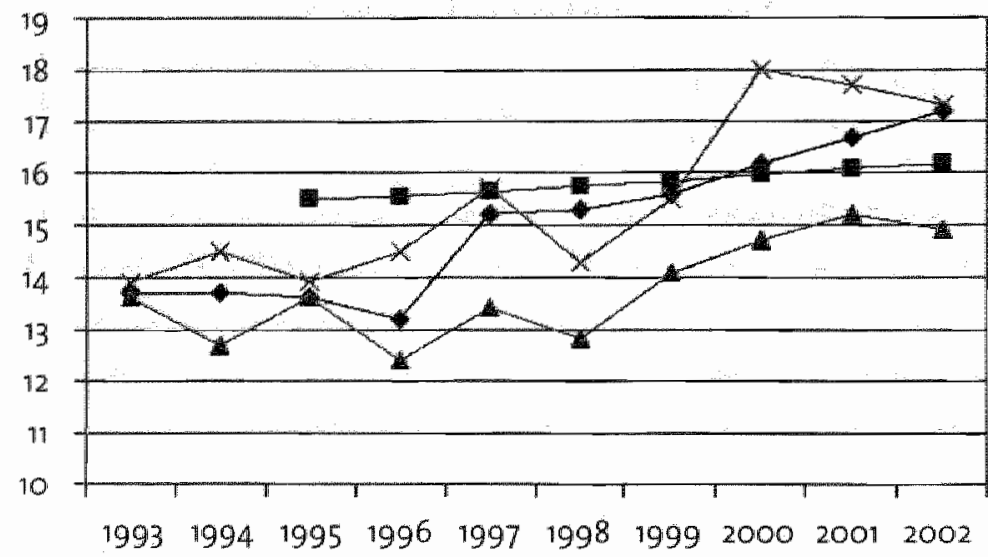

- \% contact met de fysiotherapeut

$\rightarrow$ Groel bevolking (milj)

- Tijdelijk in activiteiten beperkt

$\rightarrow$ Tijdelijk in activiteiten beperkt, personen $45-65$ jaar

Figurur: contact met defysiotherapeut, uitgesplitst naar doelgroep en leeftijd tus$\operatorname{sen} 1993 \mathrm{en} 2002$ 
De top ro van verwisdiagnosen in International Classification of Primary Care (ICPC) coderingen zlet er als volgt uits (zie Tabel 1).

\begin{tabular}{|c|l|c|}
\hline 1 & lage rugpin zonder uitstraling & $15,0 \%$ \\
\hline 2 & symptomen / klachten nek & $11,0 \%$ \\
\hline 3 & symdromen cervicale werve kolom & $6,9 \%$ \\
\hline 4 & symptomen / klachten rug & $6,8 \%$ \\
\hline 5 & schoudersyndromen / phs & $4,6 \%$ \\
\hline 6 & schoudersymptomen / klachten schouder & $3,3 \%$ \\
\hline 7 & symptomen / klachten knie & $3,5 \%$ \\
\hline 10 & lage rugpin met uitstraling & $3,3 \%$ \\
\hline 8 & Overig & $3 \%$ \\
\hline
\end{tabular}

Tobel t: verwijs dragnasen fysiotheraple in ICPC coderingen

Daarbij moet opgemerkt worden dat de ICPC diagnosen woor de fysiotherapeut een geringe warde hebben: zij komen veelal niet overeen met de behandeldiagnosenvary de fyslotherapeut, en ook de patient is veelal eerder geinteresseerd in een adequate behandeling dan wie hem of haar welk label opplakt.

Samenvattend zou ik kumnen stellen, dat de kans dat u gedurende uw leven niet in aanraking komt met de fyslotherapeut uiterst klein is, dus bereldt u alvast maar woor, u komt natuurlijk een keer bil de therapeut.

De kosten van de fysiotherapeutische zorg bedroegen in 1999663 miljoen voor de extramurale zorg, en als we daar de intramurale fysio- 
therapie bij optellen komen we schattenderwijs op een bedrag van E 1 miljard per jaar. Voor 2003 zullen de totale kosten van fysiotherapie ongeveer $3 \%$ van de totale kosten van de gezondheidszorg bedragen. Ter vergelijking, de kosten van de huisartsenzorg bedragen momenteel rond de $€ 2,5$ miljard per jaar, oftewel $8 \%$ van de totale kosten van de gezondheidszorg.

Deze kosten zullen in de toekomst nog stijgen, gezien de te verwachten dubbele vergrijzing (mensen worden ouder, maar hiermee neemt ook het aantal chronische zieken en aantal personen met lichamelijke klachten toe). Momenteel is al meer dan $30 \%$ van de patiënten die de fysiotherapeuten bezoekt, ouder dan 55 jaar en het aantal zittingen stijgt met de leeftijd van de patient. Vooral verzekeraars doen verwoede pogingen het aantal zittingen fysiotherapie in de hand te houden, want al hoewel fysiotherapie niet duur is per behandeling, wordt er, zoals $u$ al zag uit de cijfers, erg veel gebruik van gemaakt. Verzekeraars zijn, in het kader van de macro-uitgavenbeheersing gebudgetteerd en voeren daarorn volumebeleid. Benchmarking (oftewel toetsen aan de hand van ijkgegevens en/of indicatoren) is hierbij een belangrijk instrument?. Het gemiddeld aantal zittingen per patiënt op praktijkmiveau geldt als belangrijke indicator en er vindt splegeling plaats met andere praktijken. Zorgaanbieders en zorgverzekeraars onderhandelen alleen over het volume. Over de kwaliteit worden geen afspraken gemaakt, omdat hierwoor geen indicatoren zijn ontwikkeld".

Met andere woorden, zorgverzekeraars spiegelen verstrekte zorg aan de hand van behandelgemiddelden van voorgaande jaren en van andere zorgaanbieders en dwingen aldus fysiotherapeuten het aantal zittingen per indicatie zo laag mogelijk te houden. Dit kan ten koste gaan van de kwaliteit van de zorg.

Niet alleen de kwaliteit staat onder druk, ook dreigt er ondanks de dwangmatige volumecontrole van de zorgverzekeraars een toegankelijkheidsprobleem voor de fysiotherapie. Er ontstaat momenteel een toenemend tekort aan fysiotherapeuten, ondanks de enige jaren geleden opgeheven numerus fixus woor de studie fysiotherapie. Daarnaast, zoalls al eerder geillustreerd, zal de zorgvraag verder toenemen door de al eerder gememoreerde dubbele vergrijzing.

Voor de toegangstijd bestaan de zogenoemde 'Treekmormen' die door zorgverzekeraars en beroepsgroepen zijn afgesproken. Voor fysiotheraw pie is de norm vastgesteld op 1 week. Alhoewel openbare informatie over de aanwezigheid van toegangstijden bij fysiotherapeuten ontbreekt, spreken de zorgaanbieders zelf over "meerdere weken". Dit is lan- 
ger dan de Treeknorm. De toegangstijd loopt aan het eind van het kalenderjaar op vanwege (dreigende) overschrijding van de productie afspraken. De productie afspraken hebben in deze gevallen dus een negatief effect op de toegangstijd. Daarnaast zullen door de dreigende maatregelen met name de chronische patiernten financieel getroffen worden, waardoor zij minder of geen zittingen fysiotherapie zullen krijgen, en daardcor waarschijnlijk uiteindelijk in de veel duurdere tweedelijns zorg terecht zullen komen, of langer fysiotherapie nodig hebben omdat hun klachten in de tussentijd zijn verergerd.

Merkwaardigerwijs wordt fysiotherapie dus afgerekend op stuksproduktie; maar ontbreken kwaliteitsindicatoren en benchmarking. Daarnaast lijdt de fysiotherapie aan de onderhandelingstafel nog steeds aan het Callimero gevoel - iedereen is "groter' of 'belangrijker' dan zijzelf, en men vergeet ondertussen dat er in wetenschappelijke zin in de afgelopen 15 jaar een flinke inhaalslag is gemaakt. Fysiotherapeuten hoeven zich in wetenschappelijke zin zeker miet te schamen ten opzichte van andere medische beroepsgroepen. Er wordt in de wandelgangen wel eens geroepen dat de kwaliteit van de fysiotherapie tot éen van de best bewaarde geheimen van de gezondheidszorg behoort - u zult een fysiotherapeut er namelijk nooit over horen. Vandaar dat ik het vandaag maar eens zeg: welk paramedisch beroep is heden ten dage uitstekend wetenschappelijk onderbouwd - natuurlijk fysiotherapie. 


\section{De verwetenschappelijking van de fysiotherapie}

Momenteel, eigenlijk na vandaag, bestaan er twee leerstoelen fysiotheraple, twee paramedische leerstoelen en $\mathrm{zijn}$ er een 84 tal lectoren aan de hogescholen aangesteld die zich met fyslotheraple of paramedsche zorg bezighouden. Verder zijn er een vijfigtal gepromoveerde fysiotherapeuten dle zich bezighouden met onderzoek op het terrein van de fysiotherapie, en wordt er aan alle onderzoeksinstituten samen in Nederland door ongeveer 123 fte aan fysiotherapeutisch wetenschappeilik onderzoek uitgevoerd.

Dit likt misschien veel, maar toch leiden deze getallen bij mij niet tot een Juichstemming. Ook in onderzoeksland heeft de bezuinigingsdrift toegeslagen. De komende jaren stopt een groot aantal fondsen en onderzoeksprogramma's in de tweede en derde geldstroom met het financieren van fysiotherapeutisch of aan fysiotherapie gerelateerd onderzoek, bouwt dit langzaam af, of legt prioriteiten op andere onderzoeksdomeinen. De 123 fte onderzoekers fysiotherapie bestaat voor ongeveer de helft uit personeel dat slechte enkele jaren zal blijven en een groot deel van de lectoren op de hogescholen houdt zich uit de aard der zaak voornamelijk bezig met onderwijs.

Het is dan ook opmerkelijk dat een beroepsgroep die kennelijk zo'n groot deel van de Nederlandse bevolking tamelijk succesvol behandelt (maar daarover straks meer) geen eigen specifiek onderzoeksprogramma kent van waaruit structureel fysiotherapeutisch onderzoek geffnancierd kan worden. In het recente rapport van de Raad voor Gezondheidsonderzoek (RGO) wordt de suggestie gedaan om te komen tot een speciaal fonds waaruit, in leder geval de komende vier jaar, een aantal promovendi gefinancierd kunnen worden die onderzoek zullen verrichten in de fysiotherapie. Alhoewel ik deze geste van harte onderschrijf, blijft het natuurlijk een druppel op een gloeiende plaat. Ter vergelijking, de farmaceutische industrie en het internationale bankwezen besteden zo'n 10\% wan hun omzet aan onderzoek. Voor de fysilotheraple zou dat een bedrag van 100 miljoen per jaar betekenen dat aan onderzoek besteed zou mogen worden - u kunt zich voorstellen dat bij dergelijke bedragen alle aanwezige ondlerzoekers in de zaal in spontaan vreugdegezang uitbarsten.

Als we serieus zijn ten aanzien van onderzoek in de fysiotherapie lijkt. de instelling vam een eigen wetenschappelijk fonds, bekostigd door leden uit de contributie, een must. 
Helaas, zo ver zijn we nog niet. Momenteel wordt door de fysiotherapie-onderzoekers" gezocht naar thematische samenwerkingsverbanden, waardoor zij kennis en expertise kunnen bundelen en ook bij krappere middelen, toch een aantal belangrijke gebieden in de lucht kunnen houden: 


\section{Fysiotherapie onderzoek in Maastricht}

In het Maastrichtse richten we ons, ingebed in het onderzoeksinstituut Caphri - dat staat woor Care and Public Health Research Institute op een beperkt aantal thema's waarin fundamenteel onderzoek, diagnostiek, prognostiek, etiologie, gerandomiseerd effectonderzoek en richtlijnen dooreen lopen. Dat levert enerzijds een breed wetenschaps. gebied op, maar anderzijds geeft het ook aan hoeveel onderbouwing op evenzoveel fronten in de fys otherapie nodig is.

Ik noem twee woorbeelden van dergelijk onderzoek, en ga daarna wat uitgebreider op ontwikkeling en onderzoek naar richtilinen in.

\section{Onderzoek naar de bovenste extremiteit}

Schouderklachten vormen ongeveer zo'n 10\% van alle verwijzingen fysiotherapie, terwijl tenniselleboog en RSI klachten ook vaak voorkomen. Hoe vaak RSI klachten woorkomen is niet geheel duidelijk, al was het maar omdat deze lang miet zijn herkend en dus ook niet in een verwijscode vervat konden worden.

Toch zijn mensen met schouder/arm klachten bepaald gehandicapt heel veel dagelijkse activiteiten zijn opeens heel lastig. Kamt u vanavond thuis maar eens uw haar met de "verkeerde' arm, knipt u maar eens een stukje papier met de "verkeerde hand" of maakt u maar eens met één hand een jampot open.

Omdat de bovenste extremiteit voor de activiteiten van het dagelijks leven zo belangrijk is, besteden we er in diverse onderzoeken, veelal vanuit mulitidisciplinair perspectief aandacht aan.

Momenteel wordt door Jacques Geraets en Camiel de Bruijn bij het Instituut voor Revalidatie Vraagstukken (IRV) te Hoensbroek onderzoek gedaan naar graded activity en gedragsmatige interventies bij schouderklachten. Daarbij wordt niet alleen gekeken naar de effecten van de behandelingen $\mathrm{sec}_{\text {, }}$ mar ook naar de effecten die behandelaars hebben op de patiënten bij het geven van de interventles, en hoe goed de behandelaars hun kunstje doen. In het azM is Ludo Pennings bezig met injecties in de schouder, terwijl binnenkort beeldvormend onderzoek met behulp van ultrageluid maar de schouderregio platsvindt. lets verder van de schouder maar wel passend binnen het thema, vindt RSI onderzoek plaats door Marjon wan Eijsden, terwijl een stagiaire etiologie van RSI bestudeert. Behalve vergelijking wan Fyslotheraple versus 
Mensendieck in de behandeling van RSI in dit onderzoek, wordt ook veel aandacht besteed aan de mate van perfectionisme bij patiënten behept met deze aandoening. Het verloop van RSI wordt bestudeerd in een unieke samenwerking gedurende nu al viff jaar tussen onze stagiaires en bedrijfsartsen. Ook de biomechanische en motore componenten worden niet vergeten - stagiaires werken hierbij samen met het Roessingh revalidatiecentrum in Enschede aan EMG modellen.

$U$ merkt dat al deze projecten op werschillende manieren in elkaar grijpen, en dat er een sterke wisselwerking is tussen stagiaires en onderzoekers.

De uiteindelijke informatie die al die onderzoeken weer opleveren worden beschikbaar gesteld via het RSI kenniscentrum van de UM waar het RSI betreft, en in publicaties waar het promotieonderzoek betreft. De bedoeling is natuurlijk dat die'stukjes' uiteindelijk ook terechtkomen in reviews en richtlijnen fysiotherapie.

\section{Onderzoek naar rugklachten}

Over rugklachten is al heel veel gezegd en geschreven - de kans dat u er gedurende uw leven niet eens een keer last van krijgt is ongeveer $5 \%$. De kans op rugkklachten tijdens oraties is nog niet onderzocht, maar er zijn wel tal van gegevens bekend over de relatie tussen rugklachten en werk, stress en life events. Soms bestaat de indruk dat we zo langzamerhand alles wel weten van rugklachten - er dreigen in bepaalde gebieden zelfs al meer systematische literatuuroverzichten te verschijnen dan primaire studies, en ook het fenomeen meta-meta analyse (een systematisch literatuur overzicht van literatuuroverzichten) is op dit terrein reeds gesignaleerd.

Toch zijn we in de behandeling van rugklachten, vooral de a-specifieke vorm (dus rugklachten waar geen duidelijke oorzaak voor bestaat) nog niet erg succesvol. Aanleiding om met behulp van Bart Staal, die zelf op 18 december hoopt te promoveren, ons 'rugveld' in stand te houden. In Utrecht vindt momenteel de Albatros studie plaats: Pieter Helmhout en Chris Harts verrichten een multicenter studie onder legerpersoneel, gebaseerd op minimale krachttraining en een no-nonsense benadering een mooi contrast tegenower alle gedragsmatige interventies van het moment. Tegelijkertijd verricht Jan Kool in Zwitserland een studie in een revalidatiecentrum, waarbij de belangrijkste doelstelling is of mensen die dermate ernstige rugklachten hebben dat ze in een revalidatiecentrum komen, weer terug kunnen keren naar het werk.

Een bijzondere worm van rugklachten zijn klachten aan lage rug en 
bekken tijdens de zwangerschap. Carolien Bastiaenen en Janneke Bastiaanssen bestuderen niet alleen de ontstaanswijze en het verloop. ervan, maar ook de waarde van de fysiotherapeutische diagnostiek en het effect van fysiotherapeutische behandeling bij de aandoening.

in alle onderzoeken wordt nadrukkelijk gekeken naar de persooniljkheidsstructuur van de patienten en factoren als stress, negatieve emotionaliteit en angst voor bewegen. Doel is om binnen die onderzoeken ook subgroepen aan te kunnen wijzen, die mogelijkerwijs anders reageren op de theraple, en daarmee in toekomstige behandelingen rekening te kunnen houden.

Het aardige is dat veel van bovengenoemd onderzoek ooit als studentenprojecten is begonnen. Ook nu, of juist nu, zetten we studenten vàn zowel de Universiteit Mastricht als de hogeschool Zuyd in, om pilotprojecten, deelvragen, meetinstrumenten onderzoek en delen van grote projecten in te vullen. We hebben ook het geluk dat veel van bovengenoemde studenten terecht kunnen in de kweekvijver van de afdeling Fysiotherapie van het acadernisch ziekenhuis Maastricht. Daar vindt een veelheid aan projecten plaats in intensieve samenwerking met de capaciteitgroep Epidemiologie en andere medische disciplines.

De kwaliteit van de studenten is over het algemeen hoog - denk maar aan de Hogeschool Zuyd als wederom de winnaar wan de landelijke scriptieprijs - en studenten stromen vaak ook door in wetenschappelijk onderzoek als ze hebben meegemaakt hoe leuk het is om onderzoek te doen. Het deed me ook veel plezier om op het afgelopen jaarcongres fysiotherapie een groot aantal Maastrichtse alumni te zien die daar wetenschappelijke bijdragen hadden.

Zoals ik al memoreerde, veel wetenschappelijk werk op het terrein van de fysiotherapie belandt uiteindelijk, indien van voldoende kwaliteit, in systematische literaturoverzichten en richtijnen. 


\section{Richtlijnen}

Een richtlijn, voor de fysiotherapeuten in de zaal niet geheel onbekend, is een wetenschappelijk onderbouwde leidraad die systematische behandeling van een bepaalde aandoening of patiëntengroep mogelijk maakt. Ter vergelijking - de huisartsen kennen de zogenaam* de NHG standaarden en de verpleegkundigen de zorgprotocollen. Een probleem is echter dat tal van richtlijnen vooral bedoeld zijn om binnen een beroepsgroep te gebruiken, terwijl patiënten met bepaalde aandoeningen juist heen en weer pendelen tussen verschillende hulpver. leners - en met een beetje pech verstrikt raken in verschillende richtlijnen.

De fysiotherapie kent thans een 15-tal (EBM) richtlijnen (acuut en chronisch enkelletsel, stress- en urine incontinentie, COPD, lage rug, whiplash, osteoporose, hart revalidatie, arthrose heup en knie, acute knie, claudicatio intermittens, lage rug en manuele therapie, verslaglegging en informatieverstrekking naar de huisarts). Daarnaast bestaat er een 5tal ontwerprichtlijnen (post-operatieve fysiotherapie bij hernia, postoperatieve fysiotherapie bij meniscectomie, astma bij kinderen, RSI en bekkenpijn) en is de richtijn omtrent CVA ontwikkeld onder leiding van Gert Kwakkel in Amsterdam en bijna gereed.

Deze richtlijnen zijn uitdrukkelijk bedoeld om wetenschappelijk onderbouwde richting aan het handelen te geven - het is dus geen substituut voor kookboek geneeskunde. Gebruikers van richtlijnen zijn experts die op basis van hun vakkennis weten wanneer een richtlijn van toepassing is, en kunnen onderbouwen wanneer men ervan af moet wijken. In tegenstelling tot richtijinen in een aantal andere vakgebieden zoals de verpleegkunde, is er binnen de fysiotherapeutische richtlljnen nadrukkelijk ruimte gelaten voor het professionele oordeel en expertise van de individuele fysiotherapeut. De kreet 'richtlijn in de hand, weg met het verstand' is dan ook niet van toepassing.

Al deze richtlijnen zullen 'onderhouden' dienen te worden, waarbij de update tijd tussen de 3 en 5 jaar zal bedragen. Daarnaast worden nog enkele nieuwe richtlijnen voorzien, met name in de verbijzonderingen Fysiotherapie (kinderen, geriatrie, NVFS, NVFB en psychosomatiek) of als aanvulling op bestaande richtijnen (urge incontinentie).

De vraag naar het optimale aantal richtlijnen fysiotherapie is punt van zowel wetenschappelijke als politieke discussie. Het is duidelijk dat 
waar geen evidentie bestaat een richtlin weinig toe zal voegen, behalve uniformering van handelen.

Het lijkt raadzaam om uitsluitend Evidence Based richtlijnen te ontwerpen.

Voor onderhoud, sturing en initiëring van richtlijnen fysiotherapie zijn een aantal basisvoorwaarden noodzakelijk:

1. Wetenschappelijke en inhoudelijke aansturing;

2. Strategische planning en afstemming;

3. Infrastructuur en personeel.

De thans voor u staande hoogleraar is door het Koninklijk Nederlands Genootschap Fysiotherapie verzocht om het richtlijnenproces in wetenschappellike zin aan te sturen. De opdracht daarbij is complex.

Het updaten en de vorming van nieuwe richtlijnen dienen volgens de state of the art te gebeuren. Alle FT richtlijnen dienen volgens eenzelfde concept (matrix) transparant ontwikkeld te worden, te voldoen aan de internationale AGREE richtlijn, getoetst te worden bij de doelgroep en bij woorkeur vertaald en gepubliceerd te worden in het Engels. De hoogleraar zorgt voor de wetenschappelijke begeleiding en keuzen, en begeleidt contacten naar $C B O$ en beroepsorganisaties in binnen- en buitenland.

Samen met het KNGF en indien van toepassing de verbijzonderde beroepsgroepen fysiotherapie voert de hoogleraar de regie inzake keu. zen omtrent nieuwe richtlijnen. Meerjarenplanning en strategische afstemming tussen het Genootschap en nationale danwel internationale partners gebeurt in goed overleg tussen de partijen. Het KNGF behartigt de belangen van de beroepsgroep Fysiotherapie, terwijl de hoogleraar de wetenschappelijke input levert. Uitgangspunt is dat de richtlijnen niet meer centraal door dezelfde groep personen wordt ontwikkeld, zoals dat in het verleden het geval was, maar dat telkens expertgroepen in het land (maar ook uit het buitenland) actief richtlijnen zullen ontwikkelen, onder regie - omwille van de uniformiteit en indien nodig methodologische ondersteuning - van Maastricht. Gelukkig hoeft de hoogleraar dat niet allemaal alleen te doen, maar wordt hij bijgestaan door Erik Hendriks en medewerkers van het Nederlands Paramedisch Instituut en de UM.

Richtlijnen zijn te zien als wetenschappelijk product en als wetenschappelijke output van een geprofessionaliseerde beroepsgroep. 
Vandaar ook de noodzaak tot publicatie van de richtlijnen. in de toekomst zullen richtlijnen ook gevalideerd worden door middel van implementatie-onderzoek, evalluatie-onderzoek en benchmarking. Immers, richtlijnen die in het veld niet effectief $z$ iln, of geen invloed hebben op het zorg en behandelproces, voegen niets toe. Twee bij deze leerstoel behorende promovendi (Philip wan der Wees en Mariette Jansen) zijn intussen druk aan de slag om enerzijds het proces van updating van de richtlijnen in internationaal perspectief, en anderzijds het proces van benchmarking en indicatorenonderzoek bij richtlijnen vorm te geven. De kennisdatabanken van het Cochrane Rehabilitation and Related Therapies Field, te Maastricht, PEDro te Sydney en thet NPI te Amersfoort staan hen daarbij ter beschikking.

Omdat het proces van schrijven van nieuwe richtlijnen en update van bestaande richtlijnen intensief is (en dus duur), wordt momenteel heel hard gewerkt aan het elektronisch maken van richtlijnen en de daarbi] behorende informatievoorziening naar de fysiotherapeut. Tevens wordt op wetenschappelijke wijze onderzocht of de uitgezette richtlijnen ook daadwerkelijk de beoogde effecten behalen, en in hoeverre het mogelijk is met behulp van benchmarking en indicatoren onderzoek richtilingebruik en richtlijneffectiviteit te sturen.

Dit gebeurt in het net opgerichte Centre for Evidence Based Physiotherapy, waarin een aantal partners zich hebben verenigd, te weten het Cochrane Rehabillitation and Related Therapies. Field, te Maastricht, PEDro te Sydney en het NPI te Amersfoort woor de wetenschappelijke imput, de automatiseringsdeskundigheid van Carefor, RAAM automatiseringen en de ICT groepen van de Universiteit Maastricht, en morele, inhoudelijke en financiële support van Syntens (van het Ministerie vam Economische Zaken), het Genootschap Fysiotherapie, onderzoeksinstituut Caphri en de Capaciteitsgroep Epidemiologie.

Het Centre for Evidence Based Physiotherapy stelt zich als belangrijkste taak fysiotherapeuten te voorzien van up-tondate informatie met betrekking tot richtlijnem, $R C T$ s en systematische reviews. Daartoe zal een website worden opgezet warop full-text artikelen direct zijn 'gelinkt' aan de verwijzirgen in de richtlijnen, er continue benchmark informatie omtrent het gebruik en de resultaten van toepassing van de richtlijnen woorhanden is, en er up-to-date patientenprofielen per indicatiegebied op te vragen zijn. Op basis van deze patiëntenprofielen is 
het mogelijk om direct aan de individuele patiént aangepaste informatie af te drukken en die mee te geven alan de patiënt.

Verder zal de website de bekende PEDro database en Cochrane links bevatten.

Fysiotherapeuten die inloggen op de site, kunnen dat ofwel doen via het internet, ofwel wia het pakket dat ze nu gebruiken woor hun praktijkadministratie. De gegevensuitwisseling vindt geheel elektromisch (en afgeschermd) plaats. 


\section{Vrije toegankelijkheid}

Momenteel wordt door thet Koninklijk Nederlands Genootschap voor Fysiotherapie en vele wan haar leden geijverd voor vrije toegankelijkheid. Op het laatste jaarcongres wan 7 november jl. is er een hele middag aan besteed. Uitgebreid is aldaar gediscussieend en is ook de TNO pilot toegelicht waarin ge-experimenteerd wordt met de vrije toegankelijkheid voor de fysiotherapie. Een weelgehoord argument is dat huisartsen het veel te druk hebben en ook dat zij. generaliserend gesproken, te weinig specifieke kennis hebben van aandoeningen van het houdings-en bewegingsapparaat, noch wat een fysiotherapeut in zijn/haar mars heeft.

De discussie geeft nog geen duidelijkheid hoe vrij die toegankelijkheid moet zijn en wat het precies inhoudt. Mogen alleen een aantall 'ongevaarlijke' indicaties vrij toegankelijk zijn, of wooral chronische aandoeningen? Of wordt de fysiotherapeut vrij toegankelijk indien de patiënt al eerder op verwijzing bij de therapeut is geweest voor dezelfde klacht. Dat laatste is natuurlijk helemaal geen vrije toegang, maar eerder een repeterende klacht of gedoogvergunning.

In enkele andere landen op de wereld bestaat vrije toegankelijkheid wel. Eind $70^{\prime}$ er jaren kregen Australische fysilotherapeuten het recht om patiënten te behandelen zonder medische verwijzing ${ }^{\circ}$. Toentertijd werd deze stap gezien als extreem vooruitstrevend, en zelfs ongewenst. De wereld confederatie voor fysiotherapeuten dreigde zelfs de Australische fysiotherapeuten uit de wereldbond te stoten. In de Verenigde Staten van Amerika bestaat de vrije toegankelijkheid al in 34 staten.

In Nederland woedt de discussie volop, en wordt het zelfs als wenselijke stap gezien in de professionalisering van het beroep". Toch werken in de meeste Europese landen fysiotherapeuten nog steeds onder verwijzing van een arts.

De vraag doet zich voor of in Nederland de wrije toegankelijkheid op korte termijn ook haalbaar en wenselijk is. Buitengewoon belangrijk is dat het patiëntendossier ergens centraal op 1 plek bijgehouden wordt bij de huisarts lijkt hierwoor de meest a angewezen plek. Het is miet woor niets dat de vereniging van chronisch zieken nu nota bene zelf een elektronisch patiëntendossier bijhoudt omdat men de gevolgen van versnippering vreest. 
Vrije toegankelijkheid betekent een fysiotherapeut die een volwaardige eerstelijns hulpverlener is, een eerstelijns specialist op gebied wan het bewegingsapparaat. Deze direct toegankelijke fysiotherapeut heeft expertise op gebied van differentiaaldiagnostiek, vergelijkbaar met de huisarts. De direct toegankelijke fysiotherapeut kan direct doorverwijzen naar andere eerste of tweedelijns hulpverleners (bv de huisarts, psycholoog, orthopeed en reumatoloog), kan aanvullend diagnostisch onderzoek aanvragen (bv. beeldwormende diagnostiek of bloedonderzoek) ${ }^{12}$, en kan bepaalde medicatie geven, injecteren en voorschrijven"s.

Een belangrijk argument tegen de vrije toegankelijkheid is mogelijk het feit dat de meeste fysiotherapeuten op een of meerdere wan bovengenoemde aspecten de noodzakelijke kennis ontberen. Daarnaast kan men zich afvragen of men wel het filter van de huisarts wil missen, al was het maar alleen omwille van de efficientie en het behoud van de poortwachtersfunctie in de gezondheidszorg.

Er ligt een fikse taakopdracht voor het Genootschap, universiteiten en hogescholen om de additionele competenties die nodig zijn voor adequate directe toegankelijkheid in kaart te brengen, en te zorgen voor adequate bijscholing*4. Een deel van het bovengenoemde pakket kan natuurlijk vorm krijgen binnen de huidige opleidingen fysiotherapie, echter een masterjaar waarin de extra skills alsmede wetenschappelijke vaardigheden worden aangeleerd ligt in de rede, al was het alleen maar om met de mastertitel de al jaren voortslepende ongelijkheid tussen artsen en fysiotherapeuten te beslechten. Beide beroepsgroepen zijn dan doctorandi, alhoewel menigeen zich realiseert dat beide eigenlijk een beroepsopleiding gevolgd hebben.

Het is belangrijk te realiseren dat we ons voor wat betreft de vrije toegankelijkheid op een belangrijk kruispunt bevinden: een te lichtzinnige opvatting van de vrije toegankelijkheid en mogelijk enkele daaruit resulterende ernstige medische "blunders", kunnen de beroepsgroep zonder mankeren weer een decennium terugzetten in de tijd. 


\section{Wetenschap en fysiotherapie: een haat-liefde verhouding}

De wetenschappellike onderbouwing van de fysiotherapie heeft de laatste 15 jaar een stormachtige ontwikkeling doorgemaakt, waarbij de historische aanzet in Nederland wanuit de Capaciteitsgroep Epidemio-

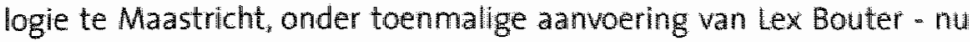
verbonden aan het EMGO instituut - gegeven werds. Slecht's in enkele jaren werden de wetenschappers binnen de fysiotherapie en wat later schoorwoetend ook praktiserend fysiotherapeuten geconfronteerd met state-of-the-art reviews ${ }^{16}$, RCTS $^{*}$ en evidence based richtlinenen ${ }^{10}$. Op conglessen, IOF besprekingen, nascholingscursussen en in de praktijk zoemt het woord 'wetenschap' rond. Ook zorgverzekeraars, beleidsmakers en verwijzers hechten waarde aan wetenschap en onderbouwing van het wak fysiotherapie Soms likt het alsof evidence based handelen een voorwaarde is woor de continuering van de beroepsuitoefening en het bestaansrecht van de professie fysiotherapie. En al zal ik de laatste zijn om te ontkennen dat wetenschap en haal gereedschap de beste onderbouwing bieden voor het vak, kritisch "boerenverstand", vooral bif ontbreken van wetenschappelijke onderbouwing, is ook een prima stuk gereedschap.

Toch blijkt er (nog steeds) een kloof te bestaan tussen wetenschappelijke onderbouwing van het vak fysiotheraphe en het daadwerkelijk gebruilk van wetenschap in de praktik. Het toenemend aantal wetenschappelijke cursussen en dito onderbouwde richtlijnen ten spijt, woor veel beroepsbeoefenaren blift wetenschap een abstracte en letwat exotische hobby. Ondanks het feit dat binnen de fysiotherapie effectonderzoek al meer dan 4 decennia usance is".

Die kloof is te verklaren uit een aantal factoren. Wetenschappers gebruiken vaak jargon dat 'geleerd' moet worden, en veelal zijn wetenschappelije artikelen ook nog in een niet Nederlandse taal geschreven. ook is de letterlike toegang tot wetenschappelljke literatuur voor fyslotherapeuten een barrière; de kreet "ik zoek het even op" kan in de praktijk leiden tot een zoektocht in databases en biblotheken die dagen kunnen duren - woor de patient die ter plekke en antwoord verwacht ronduit lastig. De drempel om wetenschappelike kennis te vergaren is dus hoog.

Daamaast blijkt dat veel wetenschappelifke artikelen slechts zeer kleine deeltjes van het spectrum beschrijwen, en dus een lage relevantie 
hebben qua toepasbaarheid van het gevondene in de praktijk. De meeste fysiotherapeuten zin immers juist geinteresseerd in het behaindelen van personen, en niet van groepen. Tenslotte, en dat blijkt ook op de cursussen Evidence Based Practice die landelijk gegeven worden, bestaat er bij cen groot aantal beroepsbeofenaars weerstand tegen het gebruik van wetenschap. Zil zijn daardoor immers veel wan hun geliefde behandelstrategieen kwijtgeraakt, en tal van bezuinigingsrondes zijn gelegitimeerd onder het mom van 'gebrek aan wetenschappelijk bewijs:

Toch zijn wetenschap en wetenschapsbeoefening geaccepteerde en geformaliseerde wijzen om de werkelijkheid te bestuderen en hanteerbaar te maken. Het juiste gebruik van wetenschap ligt in de kunst van het correct vertalen van wetenschappelijke bewindingen. Immers om in de huidige tijd een volwaardige partner te zijn in de wetenschappelijke discussie dient men enige kennis te hebben wan het wetenschapsbedrijf.

De relevantie van onderzoek is een zeer rekbaar begrip. Patienten, fysiotherapeuten, politicl, beleidsmakers en zorgverzekeraars hebben alle(n) belang bij relevant onderzoek, echter hun motieven en belangen zijn hierbij verschillend. Zo kunnen patiënten en fysiotherapeuten geïnteresseerd zijn in de kwaliteit van de zorg, terwijl de politiek de beschikbaarheid en bereikbaarheid van de zorg centraal stelt en zorgverzekeraars belang stellen in de doelmatigheid van de zorg.

Laten we ons ook eens bewust worden dat er ook veel onderzoek is verschenen waaruit zonneklaar wel degelijk een groot effect van fysiotherapeutische behandelingen blijkt - ik verwijs hierbij graag naar het recente rapport van de Gezondheidsraad waarin oefentherapie aantoonbaar en wetenschappelijk overtuigend nut heeft bij een heel scala van aandoeningen ${ }^{20}$.

Negatieve uitkomsten uit effectonderzoek leveren een aantal merkwaardige bijproducten op. Er zijn nog steeds therapeuten die van harte wensen te geloven dat het enige doel van wetenschappers is om aan te tonen dat lets niet werkt - zie de discussie in een van de laatste nummers van Fysiopraxis". Ik moet deze therapeuten teleurstellen - wetenschappers doen vooral onderzoek omdat ze willen weten of iets werkt, en neent $u$ now maar van mij aan dat het geluksgevoel van de gemiddelde promovendus behoorlijk op de proef wordt gesteld als na jaren zwoegen blijkt dat het onderzochte niet effectief is. 
Daarnaast lijken negatieve trials cen bijzonder bijeffect te genereren: met iedere negatieve trial neemt de behandelkracht van de therapeut af. Immers, om als therapeut geloofwaardig en vol vertrouwen een behandeling te kunnen geven, moet je het idee hebben dat wat je doet effectief is.

Een effectieve fysiotherapeutische behandeling bestaat uit diverse componenten, wararvan er in onderzoekstechnische zin twee het meest belangrijk zïn: de specifieke component (die wordt toegeschreven aan de specifieke interventie) en de a-specifieke component (bijvoorbeeld de attitude van de therapeut). Ten onrechte wordt deze a-specifieke component van de behandeling verward met het placebo effect. Waarschijnlijk is een groot deel van de behandelkracht van de fysiotherapeut te danken aan de aspecifieke component, die echter vooralsnog moeilijk onderzoekbaar is.

Gelukkig wordt door onderzoekers ingezien dat maximalisering van het behandeleffect afhangt van beide componenten. Vandaar dat bij wetenschappelijk onderzoek met betrekking tot de fysiotherapie bijna altijd (en zo hoort het ook) gebruik wordt gemaakt van actieve participatie van deskundige fysiotherapeuten bij de opzet en uitvoering van effectonderzoek. 


\section{Toekomstig onderzoek}

Alhoewel de RCT vooralsnog het paradigma bliff binnen fysiotherapeutisch onderzoek, zullen ook nieuwe onderzoeksvormen hun intrede doen. Ik heb u al gewezen op het belang wan indicatorenonderzoek in het kader van richtlijnenontwikkeling binnen de fysiotherapie.

Ook systematische reviews zullen in de toekomst belangrijk blijven, alhoewel de wijze waarop we deze verrichten zullen veranderen. Alhoewel het nog steeds Cochrane doctrine is om in het kader van systematische reviews zo ver mogelijk terug te gaan in de tijd om zo compleet mogelijk alle beschikbare RCTs te verzamelen, lijkt de wetenschappelijke zin ervan steeds werder omstreden. Als woorbeeld kunnen we een willekeurige review nemen waarin de eerste trial ruim 30 jaar geleden werd gepubliceerd. Het is bijna onvoorstelbaar dat in de gezondheidszorg een behandeling al die tijd hetzelfde is gebleven. Traditionele reviews tellen dus in zekere zin 'oud nieuws' bij nieuwe bevindingen op. Daar zit niemand op te wachten. Op inhoudelijke overwegingen zullen dus studies in systematische reviews geclusterd moeten worden. Overigens bestalat het gevoel dat in de fysiotherapie momenteel minder behoefte is aan systematische reviews dan aan primaire trials. Ter illustratie: er zijn al onderwerpen binnen de fysiotherapie war meer meta-analyses over het onderwerp bestaan dan primaire studies.

Ook de beoordeling van wetenschappelijke onderzoeken met zogenaamcle criteria lijsten - turflijstjes woor epidemiologen - is aan kritiek onderhevig. Er bestaat nog steeds geen consensus welke criteria absoluut essentieel zijn - dat verschilt soms per vakgebied, en ook niet welke impact goede en slechte trials in combinatie met elkaar hebben. Daarmaast is de discussie over weegfactoren in criteria lijsten, of de "levels-of-evidence" benadering. nog in volle hevigheid bezig. Onze Australische collega's hebben vorig jaar duideiljk aangetoond wat de impact van verschillende beoordelingslijsten in meta-analyses kan zijn bij gebruik van verschillende lijsten draaide het effect van de onderzochte interventie volledig om!

Het is goed ons de relatieve waarde van criterialijsten te realiseren de meeste zijn ooit ontwikkeld als didactisch hulpmiddel om studenten aan te leren hoe goed onderzoek in elkar dient te zitten - de beroemde Cochrane Back Review Group criteria list heeft zijn oorsprong achter op een blerviltje bij café het Pothuuske. 
Overigens, het invullen van criteria lijsten heeft pas echt zin ${ }^{\prime \prime}$ als wat er staat ook werkelijk te lezen valt in de primaire onderzoeken. Nog steeds verschijnen er artikelen waarvan de inhoud onduidelijk is - van het CONSORT statement hebben veel onderzoekers nog niet gehoord.

Een belangrijke ontwikkeling is onderzoek naar etiologie en prognose binnen de fysiotheraple. We raken steeds meer geinteresseerd in ontstaanswijzen van aandoeningen (en als we er dan vroeg bij zijn kunnen we misschien erger voorkomenl en als iemand de aandoening heeft. hoe het dan met hem of haar zal aflopen. Dergelijk onderzoek is niet goed mogelijk in de gebruikelijke klinische trials"2. Dure en uitgebreide cohort nested clinical trials waarbij vele duizenden patiënten gedurende langere tijd worden gevolgd zijn daarvoor nodig.

Een andere tak van sport die tot nu toe onderbelicht is gebleven is het fundamentele onderzoek in de fysiotherapie. Ik ben dan ook verheugd dat binnen mijn leerstoel ruimte is gecreëerd om daaraan aamdacht te besteden. Immers een deel van het fysiotherapeutisch kennisarsenaal baseert zich op processen die zich in de weefsels en cellen afspelen, maar geld en middelen om daar daadwerkelijk onderzoek naar te doen hebben altijd ontbroken. 


\section{De toekomst}

Ik maak nu even een sprong met $u$ naar de toekomst. Het is het jaar 2028. Met een beetje rekenwerk, ik ben wu 40 , zou dat het jaar zijn waarin ik met emeritaat ga. Een stukje van mijn afscheidsrede zou als, volgt kunnen luiden.

In de afgelopen 25 jaar hebben we een grote bloei gezien van zowel de praktijk als de wetenschap wan de fysiotherapie. Momenteel zijn er 8 structurele hoogleraren fysiotherapie (niet toevallig omdat er evenveel universitaire opleidingen fysiotherapie zijn) en 16 bijzondere (voor de verbijzonderde beroepsgroepenl.

De gevreesde bezuinigingen in 2003 van het toenmalige kabinet Balkenende zijn een 'blessing in disguise' geweest. De fysiotherapeuten hebben na actie gevoerd te hebben in dat jaar, hun zin gekregen, en de chronische patiënten zijn ontzien. Vermoedelijk omdat het kabinet doorkreeg, na actle van de verwijzend medisch specialisten, dat de tweede lijn voor dergelijke patiënten veel duurder zou zijn, maar mogelijk ook omdat in een satirisch tv programma (waarin grote hamers worden gehanteerd) een en ander nog eens lichtjes werd aangezet. De toenmalige premier, die uitstekend gepersifleerd werd, was not amused, maar de beroepsgroep kreeg zijn zin.

In de laatste decennia is het richtlijnenproces volledig geautomatiseerd "evenals benchmarking en de indicator gestuurde zorg. Met behulp van heuristische algoritmen zijn de richtlijnen, zeker bij complexere pathologie elektronisch bij te sturen (een truc die de fysiotherapeuten in 2004. van de cardiologen hebben afgekeken).

Ziektekostenverzekeraars sturen op kwaliteit - omdat dat uiteindelijk toch de meest kosteneffectieve zorg oplevert. Patiënten met gezondheidsklachten komen in aanraking met ofwel de 1e lijns arts - het woord hulsarts is rond 2010 in onbruk geraakt , met de fysiotherapeut ondanks dat er nauwelijks nog fysiotechniek gebruikt wordt leeft het woord in de volksiriond nog voort - de officiële term is nu specialist voor het bewegingsapparaat en de psycholoog. Alle drie zijn vrij toegankelijk, hebben veelal zitting in multidisciplinaire centra met eigen laboratoria en beeldvormende technieken \{de grote zlekenhuizen zijn in onbruik geraakt en vervangen door lakale care en cure centers) en verwijzen veelal gericht naar de tweede lijn.

De $r^{\circ}$ lijns arts zorgt naast zijn taken voor het compleet houden wan het elektronisch zorgdossier van de patiènt, de 1e lijns specialist voor het 
bewegingsapparaat diagnosticeert en behandelt klachten aan het houdings- en bewegingsapparaat terwijl de psycholoog voor de diagnose en behandeling van mentale en psychische stoornissen verantwoordelijk is: Daarnaast zijn er vele gespecialiseerde subdisciplines in de gezondheidszorg ontstaan, zoals beeldvormende ingenieurs, nurse specialists en patient compliance monitors.

U begrijpt echter dat woordat ik hier over 25 jaar weer sta, er nog éen en ander te doen is. Ik heb er zin in. Ik daag u uit om met mij de fysiotherapie de plaats te geven in de gezondheidszorg die zij verdient. 


\section{Dankwoord}

Een aantal mensen wil ik vanaf deze plaats bedanken voor de al dan niet bewuste invloed die zij op mij en mijn carrière hebben gehad.

In de eerste plaats Lili Pasteur, die mij gedurende de eerste schreden op het pad der fysiotherapie heeft geleerd kritisch en creatief naar de wereld te kijken. Lill, je hebt me in 1987 een fles wijn bij mijn afstuderen gegeven, met de woorden "ik hou je in de gaten". Ik hoop dat je tevreden bent, maar ik ben er nog niet.

Op de toenmalige Rijksuniversiteit Limburg kwam (en kom ik nog steeds) in aanraking met inspirerende mensen. Ik wil hier speciaal Lex Bouter noemen, mijn nestor van het eerste uur, van wie ik behalve een opgeruimd buro, inhoudelijk en organisatorisch bijzonder veel heb geleerd. Lex, veel dank voor het oppassen op mij, en je zorgen dat je op een cruciaal moment wegging in mijn carrière, zijn gelukkig geen bewaarheild geworden.

Ik wil ook de "jonge honden' van het eerste uur bedanken, die min of meer door toeval samengebracht werden in een afbraakpand van de Capaciteitsgroep Epidemiologie in de toenmalige Maastrichter Brugstraat - Pim Assendelft, Bart Koes, Geert van der Heijden, Heleen Beckerman, Erik van Rossum en Marjan Maaskant en "oppasser" Martien van Dongen. Vele inspirerende soepjes bij het Pothuuske en de daarbij] behorende gesprekken hebben ons gevormd.

In de beginjaren is er ook veel contact geweest met staf en docenten van de hogeschool Zuyd. Gelukkig is dat contact er nog steeds en werken we nog veel samen. Pieter Wolters will ik speciaal bedanken woor zijn 'organieke inzichten' en geweldige kameraadschap.

Het Genootschap Fysiotherapie en alle mij reeds dierbaar geworden medewerkers wil ik van harte bedanken woor het in mij gestelde vertrouwen en de reeds prettig vormgegeven samenwerking - ik zal mijn best doen grote sprongen te maken - jullie polsstok komt daarbij zeker van pas.

De leden van de structuurcommissie - Cor Spreeuwenberg, Onno van Schayck, Ad Borstlap en Piet van den Brandt - dank voor het vertrouwen en de plezierige samenwerking.

De afdeling Fysiotherapie van het azM geeft mij de vrijheid om me er "wetenschappel jk tegenaan te bemoeien" - ik doe dat, samen met jullie, met plezier.

De mensen waar ik nu intensief mee samenwerk, Erik Hendriks (uit- 
slapen kan altijd nog), Bart Staal (volgende week mag ji]). Thamar Bovend'eerdt (toch veel onderwijs hè) Carolien Bastiaenen (ondanks het goudvissendrama toch een vaste aanstelling), Conny en Marijke (hadden maar meer hoogleraren zon geweldig secretarlaat), mijn promovendi en vakgroepgenoten, veel dank.

Mijn collega hoogleraren Martin Prins en Piet van den Brandt, dank woor de toemoedigingen en Piet veel dank voor de wijze raad, support en wriendschap die ik in de afgelopen jaren van je macht ontvangen.

Staf en personeel van de faculteit der Gezondheidswetenschappen. jullie hebben weer een eigen kweek hoogleraar erbij - da's voor een deel jullie eigen schuld: ik heb het hier goed naar mijn zin.

Ouders en schoonouders - jullie wonen niet naast de deur - dank voor het meeleven in spannende en minder spammende tijden, en voor de morele support gedurende al deze jaren. Wetenschappers zijn dan wel solisten, maar alleen als ze zich gesteund kunnen voelen. Bij jullie was dat altijd het geval.

Martijn en Eveline, grote kleine boeven. Jullie zij nog net te klein om hier aanwezig te zijn, wat in dit jaargetijde, met een papa die er bijna uitziet als een mix tussen Sinterklaas en de Kerstman, misschien maar goed is ook. Dankzij jullie komt papa thuis weing aan werken toe. En zo hoort het ook.

Hannerieke, in mijn proefschrift schreef ik dat je het licht van mijn leven bent. Dat is nog steeds zo, maar daarnaast ben je ook nog een kel van een moeder en bezig met de laatste loodjes van je eigen promotie. Dat is een topprestatie; ik ben trots op je.

Dames en heren,

\section{Ik heb gezegd.}




\section{Referentles}

1. Landelihe Informatiewoonziening Paramedische Zorg, 2003

2. Landelikk Informatie Netwerk Huisartsen 2001.

3. Centratal Buro voor de 5tatistiek 2003.

4. Uunk W, Dekker I, Groenewegen P. Verwijingen van huisartsen naar fysiother apeuten: morbiditeitsspecifieke verwispercentages 1991.

5. Landelike Informatievoon zlening Paramedische Zorg 200 .

6. Advies onderzoek tysiotherapie, RGO publicatie 42, Den Haag 2003.

7. Plas M, Hofhuis $H$, Dorgelo et al. Kwaliteitsbewordering Paramedische Zorg. Evaluate richtijnen, standaarden en protocollen, Utrecht, mei 2001 .

8. De markt woor fysiotheraple, en oefentherapie Cesar en Mensendieck, KPMG gezondheidszarg. Hoofddorp, 2002.

9. Philipsen, H. (1997). 4. Vraggestuurde zorg: het belang van professionele fun dering van de 'erkende vragg' naar zorg. Vraaggestuurde zorg: dilemma"s en nieuwe opties bil management, primair zorgproces, newerken, automatisering, Iexibele zorgprodukten, indicatiestilling. L. Boon. Amstelveen, Stichting Sympoz, Platform voor ontwikkelingen in de gezondheidszorg. $24: 22-27$.

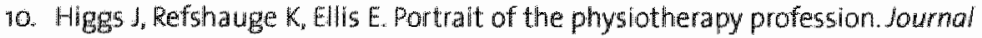
of interprofessional Core 2001;5:79-89.

11. Massey B. APTA Presidential Address: What's all the fuss about direct access? Physical Therapy 2002;82:1120-1123.

12. Ellis B, Kersten P. Physlotherapists working as extended scope practitoners. British Joumal of Therapy and Rehabilitation 2003;10: 6-17.

13. Physiotheraplsts experience of implementing their injection therapy skills. Physiotheropy 2001;89:145-157.

14. Thomas 5. Cross J, Harden B, ten Hove R. Competence in on-call physiotherapy part one: designing a framework. Internotional joumal of Therapy and Rehabilitation 2003110:321-327.

15. Bouter $L M$, Riet $G$ tr. Meta-analyse voor fysiotherapeuten. Ower het belang van standaardisering en blindering bij literatuuronderzoek. Ned Tijdschr Fysiother 199:101:49-51.

Beckerman H. Bouter LM. Effectiviteit van fysiotherapie: een literatuuronderzoek. Rijksuniversiteit Limburg, Maastricht $199 \%$

16. The Cochrane Library, Update Software, Oxford, issue 4, 2003.

17. Beurskens Al, Vet HCW, Koke AJ de et all. Efficacy of traction for non-specific low back pain: a randomised cinical trial. Lancet 1995;340:1596-1660.

Hejden GMG van der. Shoulder disorder treatment: efficacy of ultrasound therapy and electro therapy. Thesis, Maastricht Universily, 1906.

Ble Ra de. Efficacy of $g$ o4 nm laser therapy in ankle sprains. Thesis. Maastricht Univer sily 1997.

18. RA de Bie MAMB Heemskerk, Af Lensser et al. Clinical practice guidelines for physical therapy in patients with chronic ankle sprain. KNGF,2003. E.M.H.M. Vogells" H.J.M. Hendriks", M.E. wan Baarit. KNGF Clinical Guideline Osteoar thritis of the Hip or Knee, KNGF $200 \mathrm{~g}$ 
19. Fountain FP, Gersten JW. Sengir O Decrease in muscle spasm produced by ultrasound hot packs and infrared radiation. Arch Phys Med Rehabil 1960;293298.

20. Efectiviteit van oefentheraple. Cezondherdsond 2003 .

21. Melis 8. Op weg naar andersoortig onderzoek - de reacties. Fysiopraxis oktober $2003 ; 36-39$.

22. Vusuf $S_{n}$ Wittes J, Probstfield J, Tyroler HA. Analysis and interpretation of treatment effects in subgroups of patients in randomized clinical trials IAMA $1996 ; 266: 93-8$.

Herbert RD. Critical appraisal of clinical trials, ll estimating the magnitude of treatment effects when outcomes are measured on a continuous scale. Australian Journal of Physio therapy 2003:46:229-235. 
